\title{
Salvia cacomensis (Lamiaceae), a new species from Jalisco, Mexico
}

\section{Salvia cacomensis (Lamiaceae), una nueva especie de Jalisco, México}

\author{
Jesús Guadalupe González-Gallegos ${ }^{1 凶}$, José Guadalupe Morales-Arias ${ }^{2}$ and José Luis Rodríguez-Hernández ${ }^{2}$ \\ ${ }^{1}$ Herbario Luz María Villarreal de Puga (IBUG), Instituto de Botánica, Departamento de Botánica y Zoología, Universidad de Guadalajara-CUCBA, \\ km 15.5 carretera Guadalajara-Nogales, Las Agujas, Nextipac, Zapopan, 45110, Jalisco, México. \\ ${ }_{2}^{2}$ Instituto Manantlán de Ecología y Conservación de la Biodiversidad, Universidad de Guadalajara-CUCSUR, Av. Independencia Nacional 151, 48900 \\ Autlán de Navarro, Jalisco, México. \\ 凶xanergo@hotmail.com
}

\begin{abstract}
A new species from a botanically little known region of Jalisco, Mexico, is described and illustrated. The morphology of Salvia cacomensis J. G. González, J. Morales et J. Rodríguez is related to that of the species of sections Briquetia Epling and Tubiflorae (Epling) Epling of subgenus Calosphace (Benth.) Benth. The new taxon is distinguished by the combination of its essentially glabrous surface, the 2-flowered verticillasters, the pink to magenta corollas, and the particular dimensions of the floral bract, the calyx and the corolla.
\end{abstract}

Key words: endemic, Jalisco, Salvia section Briquetia, S. section Tubiflorae.

Resumen. Se describe e ilustra una especie nueva procedente de una región botánicamente poco conocida de Jalisco, México. La morfología de Salvia cacomensis J. G. González, J. Morales et J. Rodríguez está relacionada con aquella de las especies de las secciones Briquetia Epling y Tubiflorae (Epling) Epling del subgénero Calosphace (Benth.) Benth. El nuevo taxón se distingue por la combinación de su superficie esencialmente glabra, sus verticilastros bifloros, el color rosa o magenta de sus corolas y las dimensiones particulares de la bráctea floral, el cáliz y la corola.

Palabras clave: endémica, Jalisco, Salvia sección Briquetia, S. sección Tubiflorae.

\section{Introduction}

Salvia L. includes at least 900 species worldwide, with main centers of diversity in SW Asia, Southern North, Central and South America (Harley et al., 2004); it is 1 of the 3 richest genera of vascular plants in Mexico with approximately 292 species in the country (Villaseñor, 2004), and at the same time one of the most poorly understood. In the last 3 decades, a new impulse in the study of Mexican sages has resulted in the description of several new taxa (Ramamoorthy, 1983, 1984a, 1984b, 1984c; Ramamoorthy and Lorence, 1987; Levin and Moran, 1989; Espejo and Ramamoorthy, 1993; Turner, 1995, 1996, Klitgaard, 2007; Turner, 2008a, 2008b, 2008c, 2009a, 2009b, 2010; Bedolla et al., 2011; Martínez-Gordillo and Loazada-Pérez, 2011; Turner, 2011). However these efforts have been insufficient, because there are still new taxa to be described and some species that need to be reevaluated.

While conducting floristic research, Morales and Rodríguez discovered an interesting population of Salvia at Villas de Cacoma, Jalisco, Mexico, one of the least

Recibido: 14 junio 2011; 28 noviembre 2011 botanically explored areas of Western Mexico. We tried to identify the specimens using the publications of Epling and coworkers (1939, 1940, 1941, 1944, 1947, 1951; Epling and Mathias, 1957; Epling and Játiva, 1966), and those papers highlighted in the last paragraph, where new taxa were recently described. We have examined, since September 2008 to September 2011, Salvia collections from large and relatively small Mexican herbaria, according to the number of specimens that they harbor. In small herbaria (CIIDIR, CHAPA, CREG, GUADA, HEM, HUMO, OAX, SERO, USON, UAGC, ZEA, XALU), we examined the entire collections of Salvia including those specimens not yet identified. In large herbaria (ENCB, IEB, MEXU, XAL), we restricted the revision to specimens collected in Jalisco, those belonging to the sections related to the Salvia found at Cacoma (Briquetia Epling and Tubiflorae (Epling) Epling), and non-identified specimens. In both cases the specimens examined were photographed. All Salvia specimens from IBUG herbarium were also examined. We analyzed the type specimens of the species in sections Briquetia and Tubiflorae through a collection of digital photographs obtained from the web pages of the following herbaria: K, LD, LL, MA, MICH, MO, NY, UC, US, WU. As a result of the revision of literature and examination of 
herbarium specimens and photographs, the finding of Morales and Rodríguez could not be referred to any known species of Salvia. Here, we describe it as a new taxon related to the sections Briquetia and Tubiflorae of subgenus Calosphace (Benth.) Benth.

\section{Description}

Salvia cacomensis J. G. González, J. Morales et J. Rodríguez, sp. nov. (Figs. 1, 2).

Type: Mexico, Jalisco: munincipio de Villa de Purificación, Villas de Cacoma, 194' 53' N, 104³1'57" O, 1360 m alt., 26 Aug. 2010 (fl, fr), J. L. Rodríguez, J. G. Morales and M. G. Gama 340 (holotype: ZEA; isotypes: IBUG, MEXU).

S. venulosae similis sed petiolibus (0.9)1.2-1.9(2.2) $\mathrm{mm}$ longis, floribus 2 in verticilastris, bracteis floralibus 7.5-9 x 3.5-4 mm, pedicellis 4-5 mm longis, calycibus sine pilis glandularibus et 5 venis in labio superiore calycum.

Perennial suffrutex up to $2 \mathrm{~m}$ tall, erect, stems essentially glabrous. Petioles (9-)1.2-1.9(-2.2) cm long, diffusely covered by simple multicellular hairs with dark-red septa; blades elliptic-lanceolate to lanceolate, 5.5-8.5 cm long, (2-)2.5-3.5 cm wide, cuneate to short cuneate and sometimes oblique at the base, acuminate to long-acuminate at the apex, margin serrate and sparsely bordered by simple multicellular hairs with dark-red septa, green and glabrous above, glaucous and glabrous beneath, only with the main vein covered with simple multicellular hairs. Inflorescence (8-)11-18 cm long, nodes $0.5-1 \mathrm{~cm}$ apart toward the base, 9 to 19 verticillasters at each floral axis, the verticillasters 2-flowered, floral axis purplish red, glabrous. Floral bracts narrow ovate to oblanceolate, 7.5-9 $\times 3.5-4 \mathrm{~mm}$, purplish red, caudate at the apex, attenuate and truncate at the base, the margin entire and bordered with hairs similar to those of the blade margin, the rest glabrous, foliose, veins not visible, deciduous. Pedicels 1.5-2.5(-3) mm long, moderately covered with simple multicellular hairs with dark-red septa. Calyces 7-13 $\mathrm{mm}$ long, 2.5-3 $\mathrm{mm}$ wide at the throat, upper lip 3 -veined, margin of the throat covered with tiny conical hairs and with some simple hairs at the apex of the upper lip, the rest glabrous, purplish red throughout its surface, the lobes acute, the upper one entire. Corolla pink to magenta, covered with long flexible, simple hairs with dark-red septa, these concentrated mainly on the lips; tube 15-17 mm long, (3-)4-5 mm wide at its widest portion, ventricose, not invaginated at the base, internally naked (epapillate); upper lip 6-6.5 mm long, lower one 5-6(6.5) $\mathrm{mm}$ long, 1.4-1.6(-1.8) mm wide. Stamens included; filaments 1.5-1.6(-2.3) mm long; connective $1-1.1 \mathrm{~cm}$ long, with an acute little tooth just after the insertion with the filament; theca $0.6-1 \mathrm{~mm}$ long; a pair of staminodes present above and behind the insertion point of the filament to the corolla tube. Gynobasic horn 0.3-0.4 mm long; style 2-2.1 cm long, pilose at the apex, branches slightly exserted, the upper one longer and arcuate. Nutlets ovate, 0.8-1.2 mm long, 0.5-0.7 mm wide, light brown, and dark brown marbled, surface smooth and sparsely covered with whitish flexible hairs at the base on immature nutlets.

Taxonomic summary

Distribution, habitat and phenology. Salvia cacomensis is, to our knowledge, an endemic species restricted to 1 locality on the Pacific slope of the Sierra de Cacoma, Jalisco, Mexico. It is locally scarce. It inhabits montane cloud forest with Quercus L., Sebastiana Spreng., Ficus L., Clusia L. and Fuchsia L., at 1 300-1 400 m. It flowers and fructifies in August (- September).

Etymology. The specific epithet of this taxon refers to the area that embraces its distribution, the Sierra de Cacoma, Jalisco, Mexico.

Remarks. There are 2 Salvia subgenus Calosphace sections with species morphologically similar to the new taxon: Tubiflorae and Briquetia. S. cacomensis fits well with every character of the species in Tubiflorae: shrubs or subshrubs, blades ovate, acuminate at the apex, rounded to attenuated at the base, (2-)6 to 12-flowered verticillasters, bracts deciduous, 3-veined upper lips of the calyces or sometimes 5 -veined, pink to magenta corollas, epapillate corolla tubes, upper corolla lips longer than the lower ones, connectives entire or toothed and styles pilose. Among the species of Tubiflorae, S. tubifera Cav. and $S$. venulosa Epling are the morphologically closest relatives. The first one differs in having ovate, rounded at the base blades, (0.5-)1-3.3(-7) $\mathrm{cm}$ long petioles, lower blade surface slightly white pubescent, 6 to 8-flowered verticillasters, $3.5-5(-8) \mathrm{mm}$ long pedicels, short glandular-capitate hairs on the calyces, $24-25 \mathrm{~mm}$ long corolla tubes, (1.8-)2-2.6 cm long connectives, 1.8-1.9 mm long nutlets (table 1). The second one can be distinguished by its $5-10 \mathrm{~mm}$ long petioles, lower blade surface with purplish reticulate prominent veins, 2-6-flowered verticillasters, 2-3 x 2-2.5 $\mathrm{mm}$ floral bracts, 4-5 mm long pedicels, 5-veined upper lip of the calyces and those covered with capitate glandular hairs (table 1). All characters in the species of Briquetia also matches with the characters in the new taxon: thick herbs, blades acuminate at the apex and rounded to attenuate at the base (sometimes truncate or cordate), 3-veined upper lips of the calyces, dark blue corollas, corolla tubes ventricose, invaginated at the base, and internally epapillate, connectives entire or toothed, and styles pilose; excluding the color of the corolla (purple vs. magenta or 
Table 1. Comparison of characters between S. cacomensis and morphologically similar species

\begin{tabular}{|c|c|c|c|c|}
\hline Character & S. cacomensis & S. venulosa & S. tubifera & S. mexicana \\
\hline HABIT & $\begin{array}{l}\text { Suffrutex up to } 2 \mathrm{~m} \\
\text { tall }\end{array}$ & $\begin{array}{l}\text { Decumbent suffrutex } \\
\text { up to } 1.5 \mathrm{~m} \text { tall }\end{array}$ & $\begin{array}{l}\text { Perennial herb up to } 2 \mathrm{~m} \\
\text { tall }\end{array}$ & $\begin{array}{c}\text { Perennial herb to shrub } \\
\text { up to } 3 \mathrm{~m} \text { tall }\end{array}$ \\
\hline \multicolumn{5}{|l|}{ LEAVES } \\
\hline Petiole length $(\mathrm{cm})$ & $(0.9-) 1.2-1.9(-2.2)$ & $0.5-1$ & $(0.5-) 1-3.3(-7)$ & $1-10$ \\
\hline Blade shape & $\begin{array}{c}\text { Elliptic-lanceolate to } \\
\text { lanceolate }\end{array}$ & $\begin{array}{l}\text { Narrowly ovate to } \\
\text { ovate-elliptic }\end{array}$ & $\begin{array}{l}\text { Widely ovate (rarely } \\
\text { orbicular) }\end{array}$ & $\begin{array}{l}\text { Rhomboid-ovate to } \\
\text { ovate }\end{array}$ \\
\hline Blade size $(\mathrm{cm})$ & $5.5-8.5 \times(2-) 2.5-3.5$ & $6-9.6 \times 3-4$ & $5-16 \times 4-11$ & $6-18 \times 2.5-12$ \\
\hline Shape of the leaf base & $\begin{array}{l}\text { Cuneate to short } \\
\text { cuneate and } \\
\text { sometimes oblique }\end{array}$ & Cuneate to attenuate & $\begin{array}{l}\text { Cuneate to attenuate and } \\
\text { sometimes oblique }\end{array}$ & $\begin{array}{c}\text { Long attenuate, cuneate, } \\
\text { subcordate to rarely } \\
\text { rounded }\end{array}$ \\
\hline Shape of the leaf apex & $\begin{array}{l}\text { Acuminate to long- } \\
\text { acuminate }\end{array}$ & Acute to acuminate & $\begin{array}{l}\text { Acute to shortly } \\
\text { acuminate }\end{array}$ & Acute to acuminate \\
\hline Shape of leaf margin & Serrate & Crenate-serrate & Crenate-serrate & Crenate-serrate \\
\hline \multicolumn{5}{|l|}{ INFLORESCENCE } \\
\hline Length $(\mathrm{cm})$ & $(8-) 11-18$ & $5-15$ & $8-13(-18)$ & $30-50$ \\
\hline $\begin{array}{l}\text { Distance between the } \\
\text { lowermost nodes }(\mathrm{cm})\end{array}$ & $0.5-1$ & $1-1.5(-2)$ & $1-2.7$ & $1-3$ \\
\hline Number of verticillasters & $9-19$ & $7-10$ & $7-13$ & $(8-) 10-20$ \\
\hline Flowers per verticillaster & 2 & $2-6$ & $6-8$ & $(8-) 10-12(-20)$ \\
\hline \multicolumn{5}{|l|}{ FLORAL BRACTS } \\
\hline Shape & $\begin{array}{c}\text { Narrow ovate to } \\
\text { oblanceolate }\end{array}$ & Ovate & Lanceolate to ovate & Ovate \\
\hline Size (mm) & $7.5-9 \times 3.5-4$ & $2-3 \times 2-2.5$ & $9-12 \times 4-4.5$ & $6-12 \times 3-5$ \\
\hline Apex shape & Caudate & Acuminate to caudate & Caudate & Acuminate \\
\hline Base shape & Truncate & Truncate & Truncate & Truncate \\
\hline Duration & Deciduous & Deciduous & Deciduous & Deciduous \\
\hline \multicolumn{5}{|l|}{ PEDICEL } \\
\hline Length & $1.5-2.5(-3)$ & $4-5$ & $3.5-5(-8)$ & $3-20$ \\
\hline \multicolumn{5}{|l|}{ CALYCES } \\
\hline Size $(\mathrm{mm})$ & $7-13 \times 2.5-3$ & $8-9.3 \times 4-5.5$ & $(6.5-) 8-11 \times 3.4-5$ & $8-17(-20) \times 3-5$ \\
\hline $\begin{array}{l}\text { Number of Veins in the } \\
\text { upper lip }\end{array}$ & 3 & 5 & 3 & 3 \\
\hline Pubescence & Glabrous & Glandular-capitate & $\begin{array}{l}\text { Pilose and with short } \\
\text { glandular-capitate hairs }\end{array}$ & $\begin{array}{l}\text { Pilose, mainly on the } \\
\text { veins }\end{array}$ \\
\hline \multicolumn{5}{|l|}{ COROLLA } \\
\hline Color & Pink to magenta & Wine-red & Red to magenta & Dark blue to purple \\
\hline Tube size $(\mathrm{cm})$ & $\begin{array}{c}1.5-1.7 \times(0.3-) 0.4- \\
0.45\end{array}$ & $1.5-1.8 \times 0.4-0.5$ & $(1.8-) 2.1-2.5 \times 0.4-0.5$ & $1.5-2.5 \times 0.5-0.7$ \\
\hline Length of the upper lip & $6-6.5$ & $6-6.5$ & $5-8$ & $12-16$ \\
\hline Length of the lower lip & $5-6(-6.5)$ & $5.5-6.3$ & $2.5-5(-6)$ & $12-16$ \\
\hline \multicolumn{5}{|l|}{ NUTLETS } \\
\hline Shape & Ovate & Not seen & Ovate & Ovate \\
\hline Size (mm) & $0.8-1.2 \times 0.5-0.7$ & Not seen & $1.8-1.9 \times 1-1.2$ & $2.6-3 \times 1.8-1.9$ \\
\hline
\end{tabular}


Table 1. Continues

\begin{tabular}{|c|c|c|c|c|}
\hline Character & S. cacomensis & S. venulosa & S. tubifera & S. mexicana \\
\hline $\begin{array}{l}\text { ALTITUDINAL RANGE } \\
(\mathrm{m})\end{array}$ & $1300-1400$ & $1500-2000$ & $\begin{array}{c}(1900-) 2400-2800 \\
(-3000)\end{array}$ & $\begin{array}{c}(850-) 1400-2200 \\
(-2900)\end{array}$ \\
\hline HABITAT & Montane cloud forest & $\begin{array}{l}\text { Sub-Andean cloud } \\
\text { forest }\end{array}$ & Montane cloud forest & $\begin{array}{l}\text { Oak, pine-oak, montane } \\
\text { cloud and in tropical } \\
\text { deciduous forests }\end{array}$ \\
\hline DISTRIBUTION & $\begin{array}{l}\text { Villas de Cacoma, } \\
\text { Jalisco, Mexico }\end{array}$ & $\begin{array}{c}\text { Western and Central } \\
\text { Cordillera, Risaralda } \\
\text { and Antioquia, } \\
\text { Colombia }\end{array}$ & $\begin{array}{l}\text { Highlands from Belize, } \\
\text { Guatemala and Mexico }\end{array}$ & $\begin{array}{l}\text { Widely distributed in } \\
\text { Mexico }\end{array}$ \\
\hline
\end{tabular}

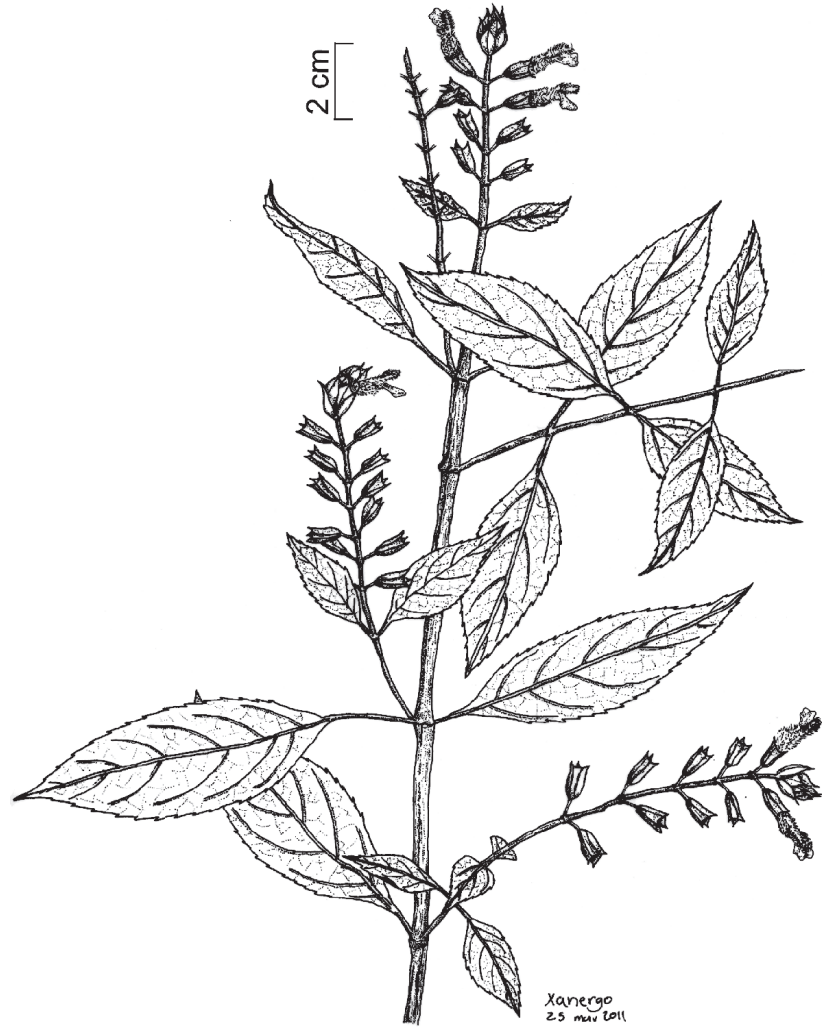

Figure 1. Salvia cacomensis J. G. González, J. Morales et J. Rodríguez. General appearance (drawn from the holotype).

pink magenta in $S$. cacomensis) and the invagination at the base of the corolla tube. However, there is a member of Briquetia which does not present invaginated corollas at the base, S. ecuadorensis Briq; and other one, which very rarely can exhibit magenta corollas, $S$. mexicana L. S. cacomensis differs from the rest of the species of section Briquetia because of its 2-flowered verticillasters (vs. 3-12-flowered), magenta or magenta-pink corollas (vs. purple ones), the length of the calyx (7-13 mm vs.
(7-)12-15 m) and corolla tube (15-17 mm vs. (11-)15-25 $\mathrm{mm})$.

Salvia cacomensis can be distinguished by the combination of its $0.5-1 \mathrm{~cm}$ long petioles, ellipticlanceolate to lanceolate blades with short to short cuneate, sometimes oblique bases and acuminate to long-acuminate apices, 2-flowered verticillasters, 7.5-9 $\mathrm{mm}$ long floral bracts, calyces without glandular capitate hairs, 3-veined upper lips of the calyces, pink to magenta corollas, with the lower lip as long as the upper one and straight.

In the region where $S$. cacomensis inhabits (Jalisco), only 2 members of section Tubiflorae (S. pringlei B. L. Rob. and Greenm. and S. tubifera), and only 1 of section Briquetia (S. mexicana) are found. None of them share habitat with $S$. cacomensis. Salvia pringlei inhabits tropical lowlands, from $400-920 \mathrm{~m}$ altitude. It can be found near the coast of Jalisco, Nayarit and Sinaloa, and in an area of the Barranca del Río Santiago in Jalisco and Nayarit. Salvia tubifera has an affinity for a colder and wetter habitat. It grows in high montane cloud forests mainly from 2 400-2 800 m altitude (Table 1). In Jalisco, this species is only known from Cerro Viejo, North of Lago de Chapala. In contrast, $S$. mexicana can occupy oak, pine-oak, montane cloud and even tropical deciduous forests, from 850-2 $900 \mathrm{~m}$ altitude in a wide area of Jalisco. Salvia venulosa, which is the morphologically most similar species to $S$. cacomensis inhabits also cloud forests and exhibits a narrow geographical range; however, this species grows in Colombia at a distance of $3500 \mathrm{~km}$ from Cacoma, Jalisco (Table 1).

As we can conclude from the above mentioned, the affinity between $S$. cacomensis with either of the 2 sections alluded is not clear. Therefore, we prefer not to assign it to either of them, and wait for new evidence and a new more natural classification than that proposed by Epling and coworkers (1939, 1940, 1941, 1944, 1947, 1951; Epling and Mathias, 1957; Epling and Játiva, 1966). 

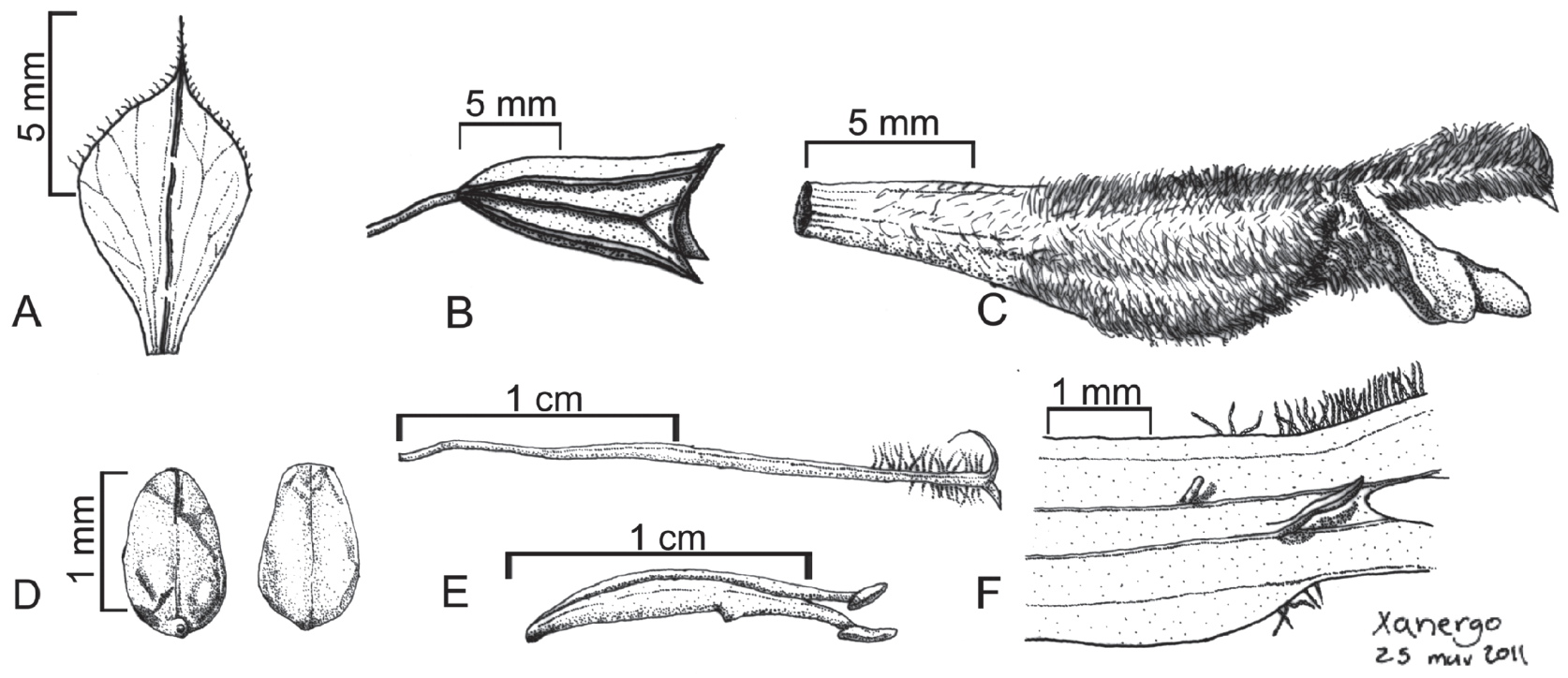

Figure 2. Salvia cacomensis J. G. González, J. Morales et J. Rodríguez. A, floral bract; B, calyx; C, corolla; D, nutlets, ventral (left) and dorsal (right) views; E, style (up) and stamens (down); F, corolla dissection showing the filament (right) and the staminode (left) (drawn from the holotype).

Key for Salvia cacomensis and closest morphologically relatives

1a Corolla dark blue to purple S. mexicana $1 \mathrm{~b}$ Corolla pink to magenta. ..................2 2a Lower corolla lip shorter than the upper one and bent backward. S. tubifera $2 \mathrm{~b}$ Lower corolla lip as long as the upper one and straight, directed forward. . .3 3a Petioles $0.5-1 \mathrm{~cm}$ long; blades narrowly ovate to ovate-elliptic, long attenuate at the base; verticillasters 2 to 6 -flowered; floral bract 2-3 mm long; calyces with glandular capitate hairs, the upper lip 5-veined. Endemic to Western and Central Cordillera, Risaralda and Antioquia, Colombia S. venulosa 3b Petioles (9-)1.2-1.9(-2.2) cm long; blades elliptic-lanceolate to lanceolate,cuneate to short cuneate at base (sometimes oblique) verticillasters 2-flowered; floral bract 7.5-9 $\mathrm{mm}$ long; calyces without glandular capitate hairs, the upper lip 3-veined. Endemic to Sierra de Cacoma, Jalisco, Mexico. S. cacomensis

\section{Acknowledgments}

We thank the curators and colleagues from the following herbaria, who kindly gave permission and helped us with the examination of herbarium specimens: CHAPA, CIIDIR, CREG, ENCB, GUADA, HUMO, IBUG, IEB, HEM, MEXU, OAX, SERO, UAGC, USON, XAL, XALU, and ZEA. We also thank the authorities of $\mathrm{K}, \mathrm{LD}, \mathrm{LL}, \mathrm{MA}, \mathrm{MICH}, \mathrm{MO}, \mathrm{NY}, \mathrm{UC}$, US, and WU, who provided online photographs of type specimens harbored in their collections through their herbaria web pages. Robin Middleton reviewed and helped to improve the writing and spelling of the document. The latin specialist, Juan Acosta Aguilar, improved our diagnoses. Economic support was provided by Consejo Nacional de Ciencia y Tecnología (CONACYT) and the Universidad de Guadalajara.

\section{Literature cited}

Bedolla-García, B. Y., S. I. Lara-Cabrera and S. Zamudio. 2011. Dos nuevas especies de Salvia (Lamiaceae) del Centro Occidente de México. Acta Botanica Mexicana 95:51-63.

Epling, C. 1939. A revision of Salvia subgenus Calosphace. Feddes Repertorium Specierum Novarum Regni Vegetabilis, Beihefte 110:1-383.

Epling, C. 1940. Supplementary notes on American Labiatae. Bulletin of the Torrey Botanical Club 67:509-534.

Epling, C. 1941. Supplementary notes on American Labiatae-II. Bulletin of the Torrey Botanical Club 68:552-568.

Epling, C. 1944. Supplementary notes on American Labiatae-III. Bulletin of the Torrey Botanical Club 71:484-497.

Epling, C. 1947. Supplementary notes on American Labiatae-IV. Bulletin of the Torrey Botanical Club 74:512-518.

Epling, C. 1951. Supplementary notes on American Labiatae-V. 
Brittonia 7:129-142.

Epling, C. and C. Játiva. 1966. Supplementary notes on American Labiatae-IX. Brittonia 18:255-265.

Epling, C. and M. E. Mathias. 1957. Supplementary notes on American Labiatae-VI. Brittonia 8:297-313.

Espejo S., A. and T. P. Ramamoorthy. 1993. Revisión taxonómica de Salvia sección Sigmoideae (Lamiaceae). Acta Botanica Mexicana 23:65-102.

Harley, R. M., S. Atkins, A. L. Budantsev, P. D. Cantino, B. J. Conn, R. Grayer, M. M. Harley, R. de Kok, T. Krestovskaja, R. Morales, A. J. Paton, O. Ryding and Upson. 2004. Labiatae. In The Families and Genera of Vascular Plants VII. Flowering Plants. Dicotyledons. Lamiales (except Acanthaceae including Avicenniaceae), J. W. Kadereit (ed.). Springer, Berlin. p. 167275.

Klitgaard, B. B. 2007. Three new species in Salvia subgenus Calosphace (Lamiaceae) from Mesoamerica. Novon 17:206211.

Levin, G. A. and R. Moran. 1989. The vascular flora of Isla Socorro. Memoirs of the San Diego Society of Natural History 16:5-71.

Martínez-Gordillo, M. and L. Lozada-Pérez. 2011. Una nueva especie de Salvia (Lamiaceae) de Guerrero, México. Brittonia 63:211-214.

Ramamoorthy, T. P. 1983. Two new species in Lamiaceae from Mexico. Anales del Instituto de Biología de la Universidad Nacional Autónoma de México. Serie Botánica 54:157-158.

Ramamoorthy, T. P. 1984a. A new species of Salvia (Lamiaceae) from Mexico. Brittonia 36:297-299.

Ramamoorthy, T. P. 1984b. A new species of Salvia (Lamiaceae) from the Sierra de los Tuxtlas, Mexico. Plant Systematics and
Evolution 146:141-143.

Ramamoorthy, T. P. 1984c. Notes on Salvia (Labiatae) in Mexico with three new species. Journal of the Arnold Arboretum 65:135-142.

Ramamoorthy, T. P. and D. H. Lorence. 1987. Species vicariance in the Mexican flora and description of a new species of Salvia (Lamiaceae). Bulletin du Muséum National d'Histoire Naturelle. Section B, Adansonia: Botanique Phytochimie 9:167-175.

Turner, B. L. 1995. Salvia booleana (Lamiaceae), a new species from Northeastern Mexico. Phytologia 79:289-292.

Turner, B. L. 1996. A new species of Salvia (sect. Caducae) from Guerrero, Mexico. Phytologia 81:329-332.

Turner, B. L. 2008a. Salvia acerifolia (Lamiaceae), a new species from Michoacán, Mexico. Phytologia 90:138-140.

Turner, B. L. 2008b. A new species of Salvia (Lamiaceae) from Guerrero, Mexico. Phytologia 90:141-143.

Turner, B. L. 2008c. Recension of Salvia sect. Farinaceae (Lamiaceae). Phytologia 90:163-175.

Turner, B. L. 2009a. Recension of the Mexican species of Salvia (Lamiaceae), section Scorodonia. Phytologia 91:256-269.

Turner, B. L. 2009b. Recension of the Mexican species of section Uliginosae of Salvia (Lamiaceae). Phytologia 91:440-465.

Turner, B. L. 2010. Recension of the Mexican species of Salvia (Lamiaceae), sect. Peninsularis. Phytologia 92:20-26.

Turner, B. L. 2011. Recension of Mexican species of Salvia sect. Standleyana (Lamiaceae). Phytoneuron 23:1-6.

Villaseñor, J. L. 2004. Los géneros de plantas vasculares de la flora de México. Boletín de la Sociedad Botánica de México 75:105-135. 